\title{
Arbetslöshet och familjerelationer
}

\author{
LEIF R. JÖNSSON
}

\begin{abstract}
Under 1990-talets ekonomisk a kris drabbades hundratusentals människor av arbetslöshet. Det var inte bara arbetare som drabbades utan också tjänstemän. Trots detta finns det få studier som uttryckligen belyser hur tjänstemän och deras familjer påverkas av arbetslösheten. Denna artikel skall ses som ett bidrag till att fylla ett slikt tomrum $i$ arbetslöshetsforskningen. Studien fokuserar på en aspekt av arbetslöshetens konsekvenser, nämligen: hur påverkar arbetslöshetssituationen stämningen mellan de vuxna $i$ familjen och mellan föräldrar och barn?
\end{abstract}

\section{Inledning}

\section{Bakgrund}

Arbetslöshetens konsekvenser har belysts i åtskilliga studier. Ett vanligt förekommande tema är arbetslöshetens ekonomiska konsekvenser. Ett annat frekvent tema är psykosociala konsekvenser (Lenkerd, 1995). Det

Leif R Jönsson är fil.lic. i socialt arbete och doktorand vid Socialhögskolan i Lund. Han är också verksam vid Utvecklingsnämnden Helsingborgs stad, som omvärldsanalytiker med inrikting mot socialpolitik.

Tacknot: Författaren vill tacka de båda anonyma referees och professor Bengt Starrin för konstruktiv kritik och värdefulla synpunkter på tidigare version av artikeln. tycks också råda en ganska stor enighet bland forskare om att arbetslösheten inte enbart berör den som mist sitt arbete, utan även fårkonsekvenser för anhöriga och andra närstående. Men detta är en aspekt som är lite belyst, i varje fall för svenskt vidkommande (Näsman \& Gerber, 1996; Starrin, 1997).

Studier om familjerelationernasbetydelse har till stor del handlat om familjen som buffert och socialt stöd i arbetslöshetssituationen (Hayes \& Nutman, 1981; Kessler, m.fl.,1987; Liem \& Liem, 1988; Engbersen, m.fl., 1993). Men det finns ocksåstudier som visat att arbetslösheten kan vara en källa till spänningar inom familjen (Flanagan,1990; Christofersen Nygaard, 1994, 1995; Björ- 
nung-Andersson \& Garsten, 1997). Lenkerd (1995) har i en översiktsstudie pekat på att relationen mellan människor är dynamisk och komplex och att det därför inte finns inga enkla samband mellan arbetslöshetssituation och familjerelation.

\section{0-talet arbetslöshetskris- konsekvenserför familjerelationerna}

Inspirationen till denna studie är hämtad från iakttagelser som arbetslöshetsforskarna gjorde under 1930-talets arbetslöshetskris. Det är också från denna tid som vi finner de första mer systematiska studierna över hur arbetslösheten påverkat förhållandena i de familjer som drabbades. ${ }^{1}$

Jahodas (1933/1971) klassiska undersökningen av arbetslösheten i Marienthal var en av de första som uppmärksammade att arbetslösheten även inverkade på familjerelationerna. Kunskapen om vilka effekter som arbetslösheten hade på stämningen i familjen kom i huvudsak från samtal med kvinnorna i de undersökta familjerna. I några familjer hade arbetslöshetssituationen en positiv inverkan, t.ex. att maken upphörde med sitt alkoholmissbruk eller att mannen deltog mer i hemarbete och barnpassning. I andra fall uppstod spänningar och gräl mellan makarna i familjer som tidigare haft en god stämning. På det hela taget föreföll det ändå bara vara i sällsynta fall

1 Rowntree \& Lasker's studier över arbetslösheten i York 1911 omnämns, av Marie Jahoda i en intervju med David Fryer, som den första systematiska sociografiska studien av arbetslöshetens konsekvenser (Fryer 1992). som arbetslösheten påverkade familjerelationerna i positiv riktning. I tidigare lyckliga äktenskap kunde grälen bli något vanligare och i problemäktenskap förvärrades problemen. Barnen drabbades hårt av de minskade ekonomiska resurserna, men det påverkade enligt forskarna inte föräldrarollen eller föräldrarnas auktoritet.

I en studie, där Eisenberger och Lazarfeld (1938) gick igenom 112 artiklar om arbetslöshetens konsekvenser, konstaterades att barnen for mycket illa av föräldrarnas arbetslöshet. De känslomässiga relationerna i familjen påverkades negativt, vilket bl.a. medförde att barnens skolprestationer och hälsotillstånd försämrades. De arbetslösa blev mer känslomässigt instabila än de var innan de blev arbetslösa. Särskilt faderns arbetslöshet föreföll vara belastande för stämningen i familjen.

En undersökning i Marienthalforskarnas anda är Komarovskys (1940/1971) studie ${ }^{2}$ om relationen mellan mannens roll som familjeförsörjare och hans auktoritet som familjeöverhuvud. I en stad utanför New York djupintervjuades 59 familjer, där mannen ifamiljen hade varit arbetslös under minst ett år. Bland de intervjuade fanns både arbetare och tjänstemän. Komarovsky fann att arbetslösheten i en del familjer, ungefär två av tio, ledde till att faderns auktoritet som familjeöverhuvud urholkades när han inte längre kunde försörja familjen. De konflikteroch den bitterhet som uppstod mellan

2 Fryer (1992) skriver att Lazarsfeld planerade en andra sociogafisk studie (Marienthalstudien var den första), denna gång över arbetslösheten i New Jersey, men planen förverkligades inte. Förmodligen, skriver Fryer, är Komarovsky studie, från 1940, den enda delen som genomfördes.

Leif R. Jönsson: Arbetslöshet och familjer 
makarna och mellan fadern och tonårsbarnen hängde samman med ekonomiska svårigheter. Hon fann också att arbetslösheten i en del fall ledde till skam- och skuldkänslor hos den arbetslöse och hans familj och i några familjer till självpåtagen social isolering.

\section{Arbetslöshet och familjerelationer i modern forskning}

I senare studier framhåller Jahoda (1980, 1982, 1992) att det inte är skäligt att jämföra ekonomiska konsekvenser av arbetslöshet idag med 1930-talet. De nutida levnadsförhållandena kan inte jämställas med den fattigdom och nöd som under depressionsåren drabbade de arbetslösa. Men Jahoda menar emellertid att socialpsykologiska effekter av arbetslösheten är viktiga att uppmärksamma även idag. 1930-talets kunskaper om hur familjer och barn drabbades av arbetslösheten kan delvis ligga till grund för att förstå dagens arbetslöshet. Att ekonomiska svårigheter, som ofta är en konsekvens av arbetslösheten, kan ge upphov till psykisk ohälsa, har påvisats i olika studier under de senaste årtiondena (se t.ex. Dhooge \& Popay, 1987; Whelan, 1992). Madge (1983) bl.a. påpekar i sin forskningsöversikt att det sociala sammanhang som arbetslösa familjer lever i har avgörande betydelse för hur de påverkas av arbetslösheten och inte minst påverkas barnens situation.

Dail (1988) visar att det finns samband mellan arbetslöshet och slitningar i äktenskapet och relationen mellan föräldrar och barn. Ekonomiska problem var den faktor som mest påverkade relationerna. Resultaten bekräftas i flera olika fallstudier om arbetslöshetenskonsekvenser(t.ex. Broman, m.fl., 1990; Conger, m.fl., 1990) Kombination arbetslöshet och ekonomiska svårigheter förefaller vara en särskilt viktig riskfaktor (Vosler, 1991).

Fagin och Little (1984) intervjuade 22 arbetslösa familjer och par vid två tillfällen med ca sex månaders intervall. När en familj drabbades av arbetslöshet visade sig både svagheter och styrkor i familjerelationerna. I en del familjer ledde arbetslösheten till ökad stress som gav upphov till ökade spänningar och barnen tappade respekt för sina föräldrar. Stressen hade samband dels med den förändring av livssituationen, som det innebar att vara utan arbete dels det stigma som det innebar att vara utan ett lönearbete. Detta bekräftas av Liem och Liem (1988), som i en longitudionell studie följde 87 arbetslösa familjer där mannen varit arbetslös under ett år. Varje familj matchades med en icke arbetslös familj. Bland familjer där mannen var arbetslös rapporterades signifikant fler familjekonflikter än bland kontrollfamiljerna. Man fann även ett starkt samband mellan arbetslösheten och andelen skilsmässor bland de studerade familjerna. Liem och Liem menar, att även om arbetslösheten kan ses som en företeelse som drabbar en enskild individ, så påverkas sambo, maka/maka och barn av den känslomässiga stress som ofta blir en effekt av arbetslösheten.

Danska undersökningar pekar på att arbetslösheten i sig kan vara en belastande faktor för hela familjen och att barnen direkt och indirekt påverkas av föräldrarnas arbetslöshet. Det händer t.ex. att familjens 
beteendemönster förändras, barnen får inte längre ta hem kamrater eller skäms för att göra det. Risken för att barnen skall uppleva att deras föräldrar flyttar ifrån varandra ökar ju längre arbetslösheten varar (Christofersen Nygaard,1994; 1995).

I några lokala svenska studier fann forskarna samband mellan föräldrars arbetslöshet och skolbarns psykosociala hälsa. Arbetslösheten var en starkt bidragande faktor till att stämningen i familjen försämras både i förhållande till sambon och till barnen. Ekonomiska påfrestningar i samband med arbetslöshet kan ge upphov till irritation och spänningarna i familjerelationerna, men i andra fall kan arbetslösheten leda till att familjerelationerna blir bättre eller att man kommer närmare varandra. I en del familjer blir konflikterna flyktiga, medan i andra blir de djupa och långvariga (Hagquist \& Starrin, 1994; Starrin, 1997; Starrin, m.fl., 1999).

Näsman \& Gerber (1996) följde 28 arbetslösa barnfamiljer under två år. De fann att barn drabbas olika av föräldrarnas arbetslöshet. Mammas eller pappas arbetslöshet hade både positiv och negativ inverkan på barnens liv. En positiv effekt var t.ex. att föräldrarna fick bättre möjligheter att vara tillsammans med barnen. Negativa effekter var att en del barn drabbades av föräldrarnas stressreaktioner och barn i undersökningen påverkades av att familjen hade fått försämrade ekonomiska villkor. Björnung-Andersson \& Garsten (1997) fann att stämningen i familjerna ofta förändrades till det sämre och det blev tabu att tala om arbetslösheten. Man undvek att ta upp känsliga saker som man trodde kunde såra den andre. De anhöriga fick ofta skuldkäns- lor. Att inte kunna tala om problemet gav upphov till frustrationer och i vissa fall till bitterhet hos de anhöriga. Det var också vanligt att man oroade sig inför framtiden.

\section{Undersökningspopulation, syfte och avgränsning}

Under 1970- och 1980-talet expanderade den svenska välfärden och allt fler människor kom i åtnjutande av den. Samtidigt växte det fram en stor kår av offentligt anställda i stat och kommun vars uppgift var att utföra och administrera de tjänster, som är förknippade med välfärden. Under 1990-talets krisår skedde kraftiga nedskärningar i välfärdsbygget och många människor som arbetade inom välfärdssektorn ställdes utan arbete. Arbetslöshet bland offentliga tjänstemän är i stort sett en följd av dessa nedskärningar. Undersökningspopulationen i föreliggande studie utgörs av tjänstemän, i huvudsak kvinnor, anslutna till kommunaltjänstemannaförbundets arbetslöshetskassa.

Syftet med studien är att undersöka hurarbetslöshetssituationen påverkarstämningen i den arbetslöse tjänstemannens familj,mellan sambo,maka/makeoch mellan föräldrar och barn. Studien avgränsas till att undersöka vilka samband som finns mellan ekonomiska och sociala faktorer och stämningen i familjen.

\section{Metod och genomförande}

Undersökningen är en s.k. tvärsnittsstudie. Studien bygger på enkätdata som insamlades under maj och juni 1997 och omfattar hela landet. Urvalet för undersökningen

Leif R. Jönsson: Arbetslöshet och familjer 
utgörs av medlemmar i Sv. Kommunaltjänstemannaförbundets (SKTF) arbetslöshetskassa.

Vid undersökningstillfället hade förbundet i runda tal 152000 medlemmar och av dessa var 13944 registrerade som heltids- eller deltidsarbetslösa. Den könsmässiga fördelningen var 76 procent kvinnor och 24 procent män. Ett register av det här slaget är alltid i viss mån "flytande», dvs. nya tillkommer samtidigt som andra lämnar. Under 1996 var i årsmedeltal 8,2 procent av kvinnorna och 8,4 procent av männen registrerade som arbetslösa, vilket antalsmässigt motsvarar ca 9500 kvinnor och ungefär 3300 män. Per den 31 december 1996 uppgick antalet aktiva medlemmar till 154883 varav 115609 (75 procent) kvinnor och 39274 (25 procent) män. Ett år senare var medlemsantalet 151570 varav 112617 (74 procent) kvinnor och 38953(26 procent)män. I undersökningspopulationen finner vi en liten »överrepresentation" för kvinnorna, som utgjorde 80 procent

Urvalprocessen gick till på följande sätt: Ett slumpmässigt sampel ur arbetslöshetskassans register drogs så att det skulle motsvara tio procent av det totala antalet registrerade. Frågeformuläret sändes per post till dem som ingick i urvalet. Respondenterna ombads att fylla i formuläret och återsända det $\mathrm{i}$ ett bifogat svarskuvert. Tre påminnelser skickades ut. Det naturliga urvalet bestod av 1394 individer. Av dessa svarade 97 att de inte längre var arbetslösa, det egentliga urvalet blev således 1297 individer, av dessa avstod 429 (33 procent) att besvara formuläret. Totalt besvarades frågeformuläret av 868 individer (67 procent). De flesta frågorna i formuläret bestod av bundna svarsalternativ. Några frågor var öppna, och respondenterna ombads att med egna ord formulera svaret.

Tre indexvariabler har konstruerats med hjälp av faktoranalys. Variablerna har kategoriserats i ungefär tre lika stora kategorier.

Variabeln „Ekonomiska svårigheter" är sammansatt av följande frågor: "Har Du sedan Du blev arbetslös tvingats låna pengar för att klara Dina utgifter? «; »Har Du sedan Du blev arbetslös tvingats att sälja ägodelar för att klara Dina utgifter?"; Har det sedan Du blev arbetslös hänt att Du inte kunnat betala räkningar i tid, på grund av att $\mathrm{Du}$ intehaft pengar? «Svarsalternativen som gavs till dessa tre frågor var: »Ja, flera gånger", »Ja, någon enstaka gång“, „Nej«; „Om Du plötsligt skulle hamna i en oförutsedd situation, där Du på en vecka måste skaffa fram 14000 kronor, skulle Du då klara detta?" Svarsalternativ som gavs var: "Ja, utan svårigheter", "Ja, men med svårigheter", "Nej». "Hur ofta grubblar Du över hur det skall gå med Din ekonomi under de närmaste åren? " Svarsalternativ som gavs var: »I stort sett varje dag", "Några gånger i veckan", "Högst en gång i veckan", "Mer sällan än en gång i veckan", "Aldrig". (Chronbach Alpha =0,78)

Variabeln "Skamgörande erfarenheter«är sammansatt av frågorna: »Har Du varit med om att människor varit irriterade på Dig därför att Du är arbetslös? «; "Har Du sedan Du blev arbetslös varit med om att andra talat nedsättande om de som är arbetslösa?»; "Har Du upplevt att andra hållit sig undan Dig därför att Du är arbetslös?»; "Har Du känt att andra betraktat Dig som mindre kunnig därför att Du är arbetslös? «; H Har Du känt att andra betraktat Dig som lat därför att Du är arbetslös? «; »Har Du känt att andra 
inte brytt sig om det Du sagt eller det Du har gjort därför att Du är arbetslös?» Svarsalternativen som gavs till samtliga delfrågor var: ॥Ja, många gånger", "Ja, några gånger", Ja, någon enstaka gång", Nej, aldrig». (Chronbach Alpha $=0,82$.)

Variabeln "Saknar någon att prata med" är formulerad på följande sätt: „Händer det att $\mathrm{Du}$ saknar någon som $\mathrm{Du}$ kan prata mer personliga saker med?" Svarsalternativen som gavs var: "Ja, ofta", Ja, ibland", "Nej, sällan", "Nej, aldrig".

Variabeln "Känner oro inför framtiden" är sammansatt av en huvudfrågeställning: „Hur pass orolig är Du för att följande saker, inom ett år, kommer att drabba Dig och /eller Din familj?" och med följande specificeringar: „Att jag/vi får svårigheter med att ekonomin att gå ihop «; »Att jag/vi måste flytta«; "Att min livslust försämras"; »Att det uppstår svårigheter att bygga upp en bra tillvaro för mig/ossu; Att jag kommer att förlora mitt självförtroende«; »Att jag drabbas av dålig fysisk hälsau; Att jag drabbas av dålig psykisk hälsau. Svarsalternativen som gav till respektive delfråga var: "Mycket orolig", "Ganska orolig", "Något orolig", "Ej orolig". (Chronbach Alpha =0,91.)

Variabeln "Utbildning» är indelad i tre kategorier: Lägre $=\mathrm{Ej}$ fullföljt grundskola; folkskola eller enhetsskola; yrkesutbildning minst ett år utöver folkskola eller liknande; grundskola, realskola eller motsvarande; Medel = Gymnasieskola (även fackgymnasium och 3-årigt gymnasium) samt utbildning minst ett år utöver gymnasieskola (högskola/universitet utan examen); Högre =Examen från universitet eller högskola.

Endast de respondenter som besvarat frågorna om arbetslöshetssituationen påverkat stämningen mellan dem och sambo/maka/ make eller deras barn har tagits med i den fortsatta resultatanalysen. 168 respondenter var ensamstående utan barn och har således inte kunnat besvara frågorna. Dessa respondenter har därför uteslutits ur den fortsatta analysen. Frågorna som man skulle ta ställning till var formulerade enligt följande: "Anser Du att Din arbetslöshetssituation påverkat stämningen mellan Dig och Dina barn?" och "Anser Du att Din arbetslöshetssituation påverkat stämningen mellan Dig och Din sambo/maka/make?" Svarsalternativen som gavs var: "Ja, till det sämre.« » Nej, det är ingen skillnad." »Ja, till det bättre."

De respondenter som tagits med i analysen är indelade i två grupper. Grupp A består av de respondenter som var gifta eller sambo och levde i hushållsgemenskap med eller utan barn. Grupp B betår av de respondenter som hade hemmavarande barn och som levde antingen tillsammans med annan vuxen (sambo, maka, make) eller var ensamstående med sitt/sina barn. En stor andel av respondenterna (312 individer) i grupp A återfinns även i grupp B, dvs de som är gifta/sambo och har hemmavarande barn. ${ }^{3}$

\section{Resultat}

\section{Undersökningsurvalet}

I tabell 1 redovisas urvalet utifrån ett antal sociala bakgrundsvariabler.

3 Det finns ett smärre internt bortfall i de olika undergrupperna, därför är inte summan alltid 597 i grupp A och 388 i grupp B, utan varierar mellan 552-597 respektive 377-388.

Leif R. Jönsson: Arbetslöshet och familjer 


\begin{tabular}{|c|c|c|}
\hline \multicolumn{3}{|l|}{ Tabell I } \\
\hline \multicolumn{3}{|l|}{ Bakgrundsvariabler } \\
\hline & \multicolumn{2}{|c|}{$\begin{array}{l}\text { Hela populationen } \\
\qquad(\mathrm{n}=868)\end{array}$} \\
\hline & Antal & Procent \\
\hline \multicolumn{3}{|l|}{ Kön } \\
\hline Man & 175 & 20 \\
\hline Kvinna & 693 & 80 \\
\hline \multicolumn{3}{|l|}{ Ålder } \\
\hline-29 år & 136 & 16 \\
\hline 30-44 år & 361 & 42 \\
\hline 45-54 år & 235 & 27 \\
\hline 55-64 år & 136 & 16 \\
\hline \multicolumn{3}{|l|}{ Familjetyp } \\
\hline Gift/sambo utan barn & 282 & 33 \\
\hline Gift/sambo med barn & 329 & 38 \\
\hline Ensamst. utan barn & 168 & 19 \\
\hline Ensamst. med barn & 83 & 10 \\
\hline \multicolumn{3}{|l|}{ Etnicitet } \\
\hline Svensk & 686 & 81 \\
\hline l:a gen. invandrare & 128 & 15 \\
\hline 2:a gen. invandrare & 33 & 4 \\
\hline \multicolumn{3}{|l|}{ Utbildning } \\
\hline Lägre & 276 & 32 \\
\hline Medel & 461 & 54 \\
\hline Högre & 122 & 14 \\
\hline \multicolumn{3}{|l|}{ Arbetslöshet } \\
\hline Heltid & 575 & 67 \\
\hline Deltid & 279 & 33 \\
\hline Öppen & 655 & 81 \\
\hline | åtgärd & 159 & 19 \\
\hline 1-12 mån & 286 & 34 \\
\hline | 3-24 mån & 155 & 19 \\
\hline 25-36 mån & 135 & 16 \\
\hline >37 mån & 257 & 31 \\
\hline
\end{tabular}

Det framkommer av tabellen att de allra flesta är kvinnor, åtta av tio. Åldersmässigt är den största gruppen mellan 30-44 år. Sju av tio är gifta/sambo med eller utan barn och en av tio är ensamstående med barn. Ensamstående utan barn utgör 20 procent av populationen (dessa kommer inte att medtagas i resultatanalysen - se metodav- snittet). Två tredjedelar är heltidsarbetslösa och nästan hälften har varit arbetslösa i två år eller längre.

Medelåldern är 42 år (median 42 år och $\mathrm{s}=11,4)$ och medelarbetslöshetstiden 30 månader (median 24 månader och s=23,2).

\section{Bi- och multivariat analys}

I tabell 2 redovisas den förändrade stämningen i familjerna avseende olika sociala bakgrundsvariabler. I grupp A redovisas relationen mellan de vuxna i familjerna och i grupp B relationen mellan föräldrar och barn.

Det framgår av tabellen att män i större utsträckning än kvinnor upplever att stämningen mellan de vuxna i familjen försämrats. När det gäller förhållandet till barnen förligger det inga signifikanta könsskillnader. Det finns en tydlig åldersskillnadi materialet när det gäller stämningen mellan de vuxna i familjerna. Yngre upplever i större omfattning än äldre att stämningen försämrats, medan det inte finns några sådana skillnader i förhållande till barnen.

Några andra viktiga skillnader som vi bör notera är sambandet mellan utbildningsnivå, om man är arbetslös på hel- eller deltid, samt om man har barn eller ej och försämrat stämningsläge mellan de vuxna i familjen.

Respondenterna ombadsatt kommentera sina svar på frågorna om stämningen mellan dem och deras sambo, maka/make, barn har påverkats av arbetslöshetssituationen.

Svarsfrekvensen var mycket hög i de två undergrupper som svarade att stämningen blivit sämre alternativt bättre mellan dem och deras sambo, maka/make, medan de som angav att det inte är någon skillnad 


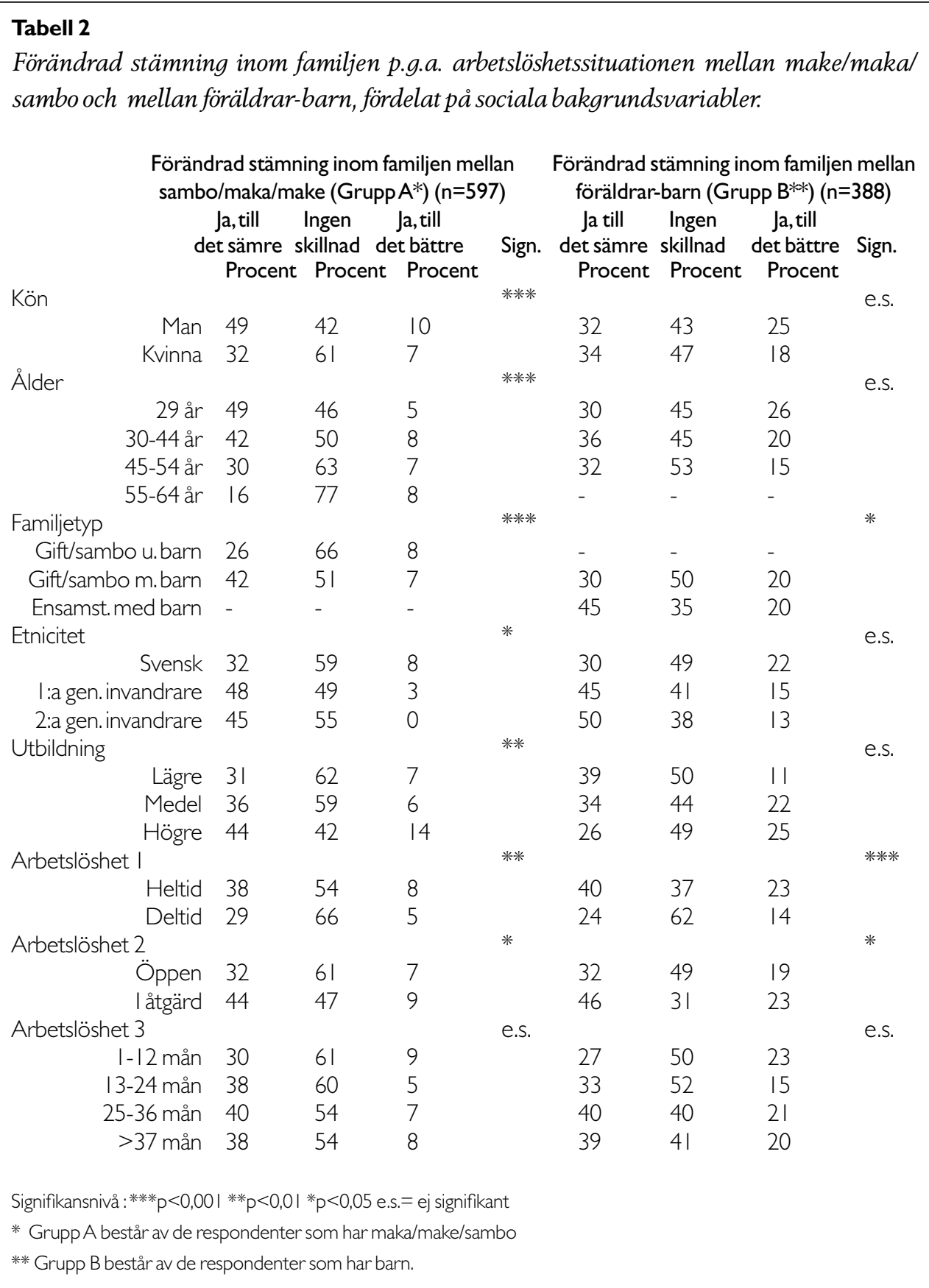

Leif R. Jönsson: Arbetslöshet och familjer 
i mycket stor utsträckning avstod från att kommentera svaret. 85 procent av dem som svarat att stämningen försämrats och 91 procent av dem som svarat att den blivit bättre kommenterade sina svar. Endast fyra procent av dem som svarade att det inte är någon skillnad kommenterade sina svar.

Svarsfrekvensen var också mycket hög avseende den öppna frågan som är kopplad till om stämningen påverkats till det sämre eller bättre i förhållande till barnen. 92 procent av dem som angivit att stämningen blivit sämre och 97 procent av dem som svarat att stämningen blivit bättre kompletterade med en kommentar. Elva procent bland dem som svarat att det inte är någon skillnad gav en kommentar.

I figur 1 redovisas några exempel på de utsagor som respondenterna skrivit i anslutning till frågeställningarna.

\section{Figur I}

Utsagor om arbetssituationens påverkan på stämningen inom familjen.

\section{Relationen mellan make/maka/sambo Grupp A (n=597)}

Försämradeekonomiska villkor. Några exempel: Kvinna 36 år, svensk, har två barn och maken är egen företagare. Kvinnan är heltidsarbetslös, men deltar i en arbetsmarknadsåtgärd. -Det är ofta tjat om ekonomin, vad man kan dra in på för att fåpengarna att räcka. Man 32 år, svensk, grundskola. Mannen är arbetslös på heltid men deltar i en arbetsmarknadsåtgärd. Sambon har anställning på heltid, men är lågavlönad. -Vi lever under ständig ekonomisk press. Det blir många gräl om vad vi skall använda dom pengar vi har till, vilken prioritering $p a ̊$ våra skulder vi skall ha. Kvinna 24 år har invandrat från annat europeiskt land, grundskola. Båda makarna är öppet arbetslösa. $-V i$ grälar ofta därför att vi klarar inte ekonomin. Kvinna, 30 år, svensk, sambon har arbete. Hon är själv deltidsarbetslös: -Det är tjat och gnat om pengar. Vi bråkar om småsaker p.g.a. att jag går hemma hela dagarna och tycket det är trist. Kvinna 29 år, svensk, paret har inga barn. Hon har examen från universitet och är öppet arbetslös på heltid. -Diskussionen om att jag blir försörjd av min pojkvän, anklagad för att göra av med för mycket pengar, [uppmaningen] ät billigare mat! Osv. Man 44 år, invandrat från utomeuropeiskt land, lägre utbildning. Mannen är öppet arbetslös på heltid och hustrun är långtidssjukskriven. Familjen har tre barn. -Vi kommer ofta $i$ konflikt om ekonomin och hushållssysslorna. Vi vet inte vart vi skall

\section{Relationen mellan föräldrar/barn Grupp B (n=388)}

Försämrade ekonomiska villkor. Några exempel: Kvinna 45 år, gymnasieutbildning. Kvinnan är heltidsarbetslös och maken har arbete. Familjen har ett barn i yngre tonåren. -Att man ofta är tvungen att säga att det har vi inte råd med, även till små saker. Man har lättare att snäsa till för att man är orolig inför framtiden. Kvinna 42 år, grundskola. Kvinnan är öppet arbetslös på heltid, maken är egen företagare. Paret har två barn. -Barnen får ofta höra att vi ej har råd. Barnen kan inte gå med $i$ föreningar som dom vill. Vi har ej åkt på semester sedan jag blev arbetslös. Man 48 år, universitetsutbildad, är i arbetsmarknadspolitiskåtgärd. Invandrad från ett utomeuropeiskt land. Hustrun har OTA. Familjen har tre barn. -Dåligt humör och dålig ekonomi påverkas mycket $i$ min stämning. Kvinna 47 år, svensk, eftergymnasial utbildning. Kvinnan är heltidsarbetslös och maken är förtidspensionerad. Familjen har tre tonårsbarn. -Det är hela tiden diskussion om pengar. Barnens aktiviteter påverkas också när det är att vi måste köra bil. Deras aktiviteter skärs ner och fickpengar är $i$ många fall obefintliga. Kvinna 45 år, svensk, eftergymnasial utbildning, heltidsarbetslös. Ensamstående med tre barn varav två i tonåren. -Ekonomin. Att allid säga nej, jag har inga pengar, att t.o.m. frysa inne veckopengen. Det är tufft att inte kunna göra något. Kvinna 34 år, svensk, heltidsarbetslös, gymna- 
göra av med alla frågor om hur framtiden ska bli. Vill ofta återvända till mitt hemland, vilket oroar sambon. Kvinna 34 år, svensk, har högre utbildning. Maken är arbetslös på heltid, paret har fem barn i åldern 4-14 år. Hon är deltidsarbetslös. -Eftersom vi båda är arbetslösa är det ständigt bekymmer om ekonomin och att kunna behailla huset.

Försämrat psykiskt välbefinnande. Några exempel: Man 46 år, svensk, grundskola, är arbetslös på deltid, hustrun har heltidsarbete. Familjen har ett barn i tonåren. -Depression, som skapar sämre relation och oförmåga att skapa ekonomisk trygghet för familjen skapar depressiva tankar. Kvinna, 35 år svensk, deltar i arbetsmarknadspolitisk åtgärd. Mannen har arbete och familjen har två små barn. -Därför att den som har arbete inte förstår hur det är att vara utan jobb. Man blir retlig och grinig och detpåverkar stämningen. Kvinna, 39 år, svensk, gymnasieexamen. Kvinnan är arbetslös och i arbetsmarknadsåtgärd, medan maken har heltidsarbete. Familjen har två barn. -Jag känner mig som en börda för samhälle och familj. Det är jag själv som tänker så, får aldrig sådana kommentarer från min familj. Jag har mycket dåligt samvete för att jag inte kan ge barnen det jag vill. Man, 25 år, svensk, har universitetsexamen, är arbetslös på heltid. Sambon har heltidsarbete. -Man blir lättare irriterad på småsaker. Man tänker negativt, mer prat om pengar. Dom säger att pengar inte gör någon lycklig, men det är skitsnack.

Om självförtroende och egenvärde. Några exempel: Kvinna, 26 år, svensk, gymnasieexamen. Kvinnan är arbetslös på heltid, men sambon har heltidsarbete. Inga barn. -Eftersom jag ofta är ledsen så märker naturligtvis min sambo detta och det gör även honomledsen. Man känner sig värdelös. Kvinna 42 år, invandrare från annat europeiskt land, yrkesutbildad. Heltidsarbetslös. Maken har anställning. Familjen har två tonårsbarn. -Jag har dåligt självförtroende, nästan ingen livslust. Ekonomin har blivit sämre, så det uppstår konflikter.. Kvinna 51 år, har eftergymnasial utbildning, är heltidsarbetslös. Maken har heltidsarbete. Familjen har två tonårsbarn. -Tyvärr upplever jag att min man och jag kommit ifrån varandra betydligt. Han har vuxit, medan jag krympt, respekteras inte intellektuellt och så bidrar jag inte så mycket med ekonomiskt. Oerhört dålig kontakt. sial utbildning. Maken har anställning. Familjen har två barn. -Man har inte råd att låta barnen vara med på en del fritidsaktiviteter. Det är svårt att få dom att förstå att vi har dåligt med pengar. Kvinna 33 år, svensk, deltar i arbetsmarknadspolitisk åtgärd på heltid, yrkesutbildning. Maken är heltidsarbetslös. Paret har två barn i skolåldern. -Man mår dåligt av att inte kunna köpa kläder till barnen t.ex. när dom verkligen är i behov av det.

Försämrat psykiskt välbefinnande. Några exempel: Kvinna 32 år, svensk, eftergymnasial utbildning. Båda makarna är öppet arbetslösa på heltid. Paret har två barn. -Dåligt humör, kortare stubin, ekonomiskabekymmer och initiativlöshet. Kvinna 23 år, svensk, gymnasieutbildad, heltidsarbetslös. Ensamstående med ett barn. -Man blir lättirriterad av att gå hemma hela dagarna. Man har inga pengar att göra saker.Detharblivitsämre sedanjagblevensam stående. Kvinna 44 år, svensk, har låg utbildning, är heltidsarbetslös. Maken har arbete. Familjen har två barn. -Jag är ofta arg och irriterad på mina barn och man. De tycker att jag kan göra allt, även när dom kommit hem. Kvinna 35 år, 2:a gen. invandrare, högskoleutbildning, öppet arbetslös på heltid. Maken har arbete. Familjen har tre barn i skolåldern. -Blir fort arg, har ingen lust att diskutera. Det är svårt att argumentera för vissa saker när man är arbetslös, som föräldrer känner man sig misslyckad. Kvinna 51 år, svensk, högskoleutbildning, öppet arbetslös på heltid. Maken har anställning. Familjen har två tonårsbarn. -Jag har blivit nedstämd och tappat gnistan samt tron på mig själv, vilket medfört att både tålamod och ork har minimerats. Vi har pratat om orsaken och min familj förstår.

Positivt. Mer tid, mindre stress. Några exempel: Man 29 år, svensk, med universitetsexamen. Mannen är arbetslös på heltid. Hustrun är egen företagare. Familjen har två barn i förskoleåldern. - Jagär merpigg och utvilad, ingen stress som påverkar barnen till att känna sig undanträngda p.g.a. arbetet. Tid att lyssna på dom och umgås. Kvinna 40 år, svensk, gymnasieexamen. Hon är öppet arbetslös på heltid och ensamstående med två tonårsbarn. -Jagär inte lika stressad och har mer tid för barnen. De uppskattar att jag är hemma när de kommer från skolan. Kvinna 36 år, svensk yrkesskola. Hon är öppet arbetslös på heltid och ensamstå-

Leif R. Jönsson: Arbetslöshet och familjer 
Positivt. Mer tid, mindre stress. Några exempel:Kvinna 33år, svensk, eftergymnasial utbildning. Kvinnan är öppet arbetslös på heltid och maken har anställning. Familjen har tre barn under tio år. -Att få mer tid för sig själv och inte så trött och stressad. Man hinner med hemarbetet på ett helt annat sätt. Kvinna 29 år, svensk, eftergymnasial utbildning. Sambon är egen företagare och kvinnan är öppet arbetslös på heltid. Paret har inga barn. -Kan träna tillsammans eftersom vi annars haft olika tider. Hinner med hemmet, ingen stress, det påverkar $i$ sin tur sex, fritid och allt. Man 63 år, svensk. Är i arbetsmarknadspolitisk åtgärd. Hustrun sjukpensionerad. -Min sjukpensionerade hustru har fätt mer omvårdnad via mig. Kvinna 33 år, svensk, eftergymnasial utbildning. Kvinnan är arbetslös på heltid och maken har arbete. Familjen har två barn i förskoleåldern. - Ärjag arbetslös sköter jag bara mitt hem och min familj, inte ett lönearbete också. Det mår vi allabra av. ende med ett barn i förskoleåldern. - Det finns inget bättre än att vara hemma med sitt barn. Det är väldigt stimulerande och meningsfullt och vi har fätt en fin kontakt. Man 33 år, invandrare från utomeuropeiskt land, öppet arbetslös på heltid, har en eftergymnasial utbildning. Hustrun studerar och paret har tre barn. -Viär tillsammans hela tiden och vi har fätt mer känslor för varandra. Kvinna 28 år, svensk, gymnasieutbildning, öppet arbetslös på heltid. Maken har anställning och paret har två små barn. - Mina barn är bara små en gång. Vi fär vara tillsammans och göra roliga saker. Jag har också ett extra vårdkrävande barn, som jag tar hand ompå bästa sätt. Kvinna 32 år, svensk, högskoleutbildad, deltidsarbetslös. Maken har arbete och paret har två barn i förskoleåldern. -Jag har mer tid över för mina barn, hinner med att se dom utvecklas och växa upp. Det sätter jag stort värde på.
Signifikanta könsskillnader kan noteras när det gäller andelen som svarade att stämningen till sambo/maka/maka försämrats. Männen tycks påverkas mer än kvinnorna. Fem av tio bland männen uppger en försämrad stämning medan motsvarande siffra för kvinnorna är ca tre av tio (se tab. 2). Det finns även könsmässiga skillnader om vad man anser orsakat den försämrade stämningen. Kvinnorna skrev i sina kommentarer i större utsträckning än männen att det är konflikter kring familjeekonomin. De ekonomiska svårigheterna ger upphov till konflikter om hur man skall prioritera mellan skulder och hur pengarna skall användas. Både kvinnor och män menar att arbetslöshetssituationen har påverkat deras humör så att de känner sig ledsna och lättare blir irriterade. Flera kvinnor har skrivit att de känner sig osjälvständiga och ekonomiskt beroende av sin partner, att de tappat sitt självförtroende och att självkänslan påverkas på ett negativt sätt.

De som anger att arbetslösheten medfört positiva förändringar framhåller i huvudsak att de upplever mindre stress och har mer tid för varandra, barnen och hemmet.

I förhållande till barnen återkommer samma grundton som mellan de vuxna. I de fall där man skriver att stämningen mellan föräldrar och barn blivit sämre spelar den försämrade ekonomin stor roll. Många skriver att de ofta tvingas säga nej till barnen då dessa vill ha pengar till olika aktiviteter, som de brukade delta i innan någon av föräldrarna blev arbetslös och ekonomin försämrades. En del tycker att det är svårt att få barnen att förstå att man inte längre har lika mycket pengar att röra sig med som före arbetslösheten och detta leder till spän- 


\begin{tabular}{|c|c|c|c|c|}
\hline \multicolumn{5}{|l|}{ Tabell 3} \\
\hline \multicolumn{5}{|c|}{$\begin{array}{l}\text { Försämrad stämningen på grund av arbetslöshetssituationen mellan sambor, maka/make } \\
\text { samt mellan föräldrar och barn och Ekonomiska svärigheter, Skamgörande erfarenheter, } \\
\text { Saknar någon att prata med samt Oro inför framtiden. (Bi- och multivariat analys.) }\end{array}$} \\
\hline \multirow[b]{3}{*}{ Ekonomiska svårigheter } & \multicolumn{2}{|c|}{$\begin{array}{l}\text { Förändrad stämning inom } \\
\text { familjen mellan sambo/maka/make } \\
\text { (GruppA) }\end{array}$} & \multicolumn{2}{|c|}{$\begin{array}{l}\text { Förändrad stämning inom } \\
\text { familjen mellan föräldrar-barn } \\
\text { (Grupp B) }\end{array}$} \\
\hline & Procent ${ }^{\text {a) }}$ & Oddskvot ${ }^{b)}$ & Procent a) & Oddskvot c) \\
\hline & $(n=584)$ & $(n=498)$ & $(n=378)$ & $(n=330)$ \\
\hline Små eller inga & 10 & 1,0 & 18 & 1,0 \\
\hline Medel & 47 & $10,62 * * *$ & 32 & 2,28 e.s. \\
\hline Stora & 60 & $23,66 * * *$ & 53 & $5,88 * * *$ \\
\hline Skamgörande erfarenheter & $(n=594)$ & $(n=505)$ & $(n=387)$ & $(n=337)$ \\
\hline Mindre & 18 & 1,0 & 19 & 1,0 \\
\hline Medel & 35 & $2,24 *$ & 30 & $3,60 *$ \\
\hline Mera & 54 & $2,97 * * *$ & 52 & $7,16 * * *$ \\
\hline Saknar någon att prata med & $(n=596)$ & $(n=505)$ & $(n=387)$ & $(n=336)$ \\
\hline Aldrig & 24 & 1,0 & 22 & 1,0 \\
\hline Ibland & 27 & |,4| e.s. & 26 & |,3| e.s. \\
\hline Ofta & 46 & $3,66 * * *$ & 71 & $19,66 * * *$ \\
\hline Känner oro inför framtiden & $(n=585)$ & $(n=496)$ & $(n=382)$ & $(n=331)$ \\
\hline Liten eller ingen & 13 & 1,0 & 12 & 1,0 \\
\hline Måttlig & 34 & $6,10 * * *$ & 24 & $3,9 \mid * * *$ \\
\hline Stor & 62 & $28,05 * * *$ & 62 & $26,12 * * *$ \\
\hline \multicolumn{5}{|c|}{ Signifikansnivå multivariata värden: ${ }^{*} * *{ }^{*}<0,00$ I $* * p<0,0 \mid * p<0,05$ e.s. $=$ ej signifikant. } \\
\hline \multicolumn{5}{|c|}{ a) Procenttalen ej justerade för bakgrundsvariabler.Samtliga värden är signifikanta på 0,00 I-nivån $(p=0,000)$} \\
\hline \multicolumn{5}{|c|}{$\begin{array}{l}\text { b) Justerad för kön, ålder, öppet arbetslös eller i åtgärder, hel- eller deltidsarbetslös, utbildning, etnicitet, arbetslöshetsti- } \\
\text { dens längd och makes/makas/sambos sysselsättning. }\end{array}$} \\
\hline \multicolumn{5}{|c|}{$\begin{array}{l}\text { c) Justerad för kön,ålder,öppet arbetslös elleri åtgärder, civilstånd, hel- eller deltidsarbetslös, utbildning, etnicitet, arbets- } \\
\text { löshetstidens längd, har hemmavarande barn under } 20 \text { år och om något barn över } 16 \text { år är arbetslös. }\end{array}$} \\
\hline
\end{tabular}

ningar och konflikter. Andra orsaker som nämns är att oro inför framtiden, förlorad självkänsla, nedstämdhet, lättirriterad och dåligt humör påverkar stämningen.

Bland dem som anser att stämningen blivit bättre framhålls främst att det är stimulerande att få vara tillsammans med barnen och kunna hjälpa dem med läxor och tillbringa mer av fritiden tillsammans.

I tabell 3 redovisas sambandet mellan tre indexvariabler ${ }^{4}$ («Ekonomiska svårigheter»;
"Skamgörande erfarenheter»; "Känner oro inför framtiden") samt variabeln "Saknar någon att prata med" och hur man påverkats av arbetslöshetssituationen. Sambandet mellan dessa variabler och stämningen mellan sambo/makar och mellan föräldrarbarn förklaras med hjälp av logistisk regression.

4 Indexvariablernas konstruktion och sammansättning finns beskrivet i metodavsnittet. 
De procentuella värdena i tabellen visar ett generellt mönster, ju svårare situationen upplevs desto större andel rapporterar försämrad stämning mellan de vuxna i familjen. De största skillnaderna finns mellan dem med små eller inga och dem med stora ekonomiska svårigheter samt mellan dem som känner liten eller ingen oro och dem som känner stor oro. Minst skillnad finner i vi i grupp A mellan dem som svarat att de aldrig och dem som angivit att de att ofta saknar någon att prata med. När det gäller relationen mellan föräldrar och barn har en något större andel, sju av tio, som ofta saknar någon att prata med angivit försämrad stämning. Det är i denna grupp vi återfinner de ensamstående med barn. Vid kontroll visade det sig att de ensamstående i högre grad än gifta/sambo svarade att de ofta saknade någon att prata mer personliga saker med (ej i tabell).

Vilken betydelse har skamgörande erfarenheter för stämningen? Upplevelser av skam är också förenat med känslor av nedvärderande slag. Vi ser att ungefär fem av tio som hade mer skamgörande erfarenheter svarade att arbetslösheten försämrat stämningen i familjen både till den andra parten och till barnen. I den multivariata analysen skiljer det däremot mellan hur stämningen påverkas mellan de vuxna och mellan föräldrar-barn. Skamgörande erfarenheter har något starkare genomslag i förhållandet till barnen än mellan de vuxna i familjerna.

Vid utsatthet har socialt stöd visat sig vara en viktig buffert. Vi har sett i tabell 2 att ensamstående i större omfattning än sambor/gifta anger att stämningen till barnen försämrats och att det faktum att det finns barn i familjen har betydelse för stämningsläget. Gift/sambo med barn upplever i större utsträckning än par utan barn att stämningen försämrats. Att ha någon att prata med om personliga saker med är ett socialt stöd och en viktigt buffert. Mindre än fyra av tio av dem som ofta saknar någon att prata med uppger att stämningen försämrats i förhållande till sambo/maka eller make, medan drygt sju av tio anger försämrad stämning i relation till sina barn. Ungefär 20 procent av barnfamiljerna består av enföräldrershushåll. Vid kontroll (ej i tabell) framkom att ensamstående ofta upplever att de saknar någon att prata med och bland kvinnor är det signifikant större andel bland ensamstående som ofta saknar någon att prata med än bland gifta (32 resp. 18 procent). Vid multivariat analys och justerat för bakgrundsfaktorer visar det sig att oddskvoten för försämrad stämningen mellan de vuxna i familjen när man ofta saknar någon att prata med, är knappt fyra gånger större än referenskategorin, medan oddskvoten är 20 gånger större när det gäller förhållandet till barnen.

Att känna stor oro inför framtiden har ett starkt samband med försämrad stämning både mellan makarna och mellan föräldrar och barn. Tillsammans med stora ekonomiska svårigheter har stor oro starkast samband med försämrad stämning mellan de vuxna i familjerna. När det gäller föräldrar-barn relationen är det stor oro och att ofta sakna någon att prata med som uppvisar starkast samband med försämrad stämning. 


\section{Diskussion}

Studiens syfte var att undersöka hur arbetslöshetssituationen påverkar stämningen $i$ arbetslösa tjänstemannafamiljer mellan makar/sambor och föräldrar-barn.

Resultatet visade att närmare fyra av tio arbetslösa tjänstemän ansåg att arbetslösheten lett till att stämningen mellan dem och deras sambo, maka eller make blivit sämre. En större andel av männen än kvinnorna upplevde att stämningen försämrats. Åldern tycks spela stor roll. Nästan häften av de yngre uppgav att stämningen försämrats mot 16 procent i den äldre kategorin. Högutbildade upplevde i högre grad än lågutbildade att stämningen försämrats. Heltidarbetslösa upplevde det i större omfattning än deltidsarbetande. Arbetslöshetstidens längd har betydelse, ju längre arbetslöshet desto större andel som anger att arbetslösheten givit upphov till att stämningen försämrats mellan dem och deras sambo, maka/make. En del rapporterade att arbetslöshetssituationen påverkat familjestämningen till det bättre mellan dem och deras partner. Familjen gör mer saker tillsammans än tidigare. Mannen deltar t.ex. mer i hushållsarbetet och är tillsammans med barnen i större utsträckning.

Ungefär en tredjedel av både kvinnor och män uppgav att stämningen mellan dem och deras barn försämrats p.g.a. arbetslösheten. Personer i yngre medelåldern rapporterade i större utsträckning än övriga att den blivit sämre. Det framkom också en skillnad mellan svenskar och utlandsfödda. De senare gav i större omfattning uttryck för att stämningen försämrats inom familjen. Lågutbildade rapporterade i större omfattning än högutbildade att relationen till barnen försämrats. Heltidsarbetslöshet och att vara iarbetsmarknadspolitiksåtgärdsamt arbetslöshetens längd påverkar stämningen till det sämre mellan föräldrar och barn. Män upplevde i större utsträckning än kvinnor att stämningen blivit bättre. Yngre rapporterade ett bättre förhållande till barnen. Framförallt var det de yngre kvinnorna gav uttryck för detta i sina kommentarer. Man upplevde det som positivt att kunna vara tillsammans med barnen när de är små. Småbarnsfamiljer upplever ofta att stämningen förbättras medan familjer med tonårsbarn att den försämras. Det framgår också av den tidigare forskningen att arbetslösa föräldrars auktoritet hotas i förhållande till tonårsbarnen.

\section{Ekonomiska och sociala konsekvenser}

Vi har kunnat konstatera att arbetslösheten har både ekonomiska och sociala konsekvenser som påverkar stämningen i de arbetslösa tjänstemannafamiljerna. Spridningseffekten påvisades redan av de forskare som studerade massarbetslöshetens konsekvenser på 1930-talet (Bakke, 1933; Jahoda, 1933/1971; Eisenberger \& Lazarsfeld, 1938; Komarovsky, 1940/1971). Under 1930-talets arbetslöshetskriser led de arbetslösa stor materiell nöd med svält och svåra umbäranden, medan det moderna välfärdssamhället har skapat buffertar som skyddar de arbetslösa från att drabbas av sådana umbäranden som på 1930-talet. Även om de ekonomiska svårigheterna inte drabbar arbetslösa lika hårt i dag som på 1930-talet så får de snarlika konsekvenser i den sociala sfären.

Leif R. Jönsson: Arbetslöshet och familjer 


\section{Skillnaderi stämningen inom familjen}

Vi har kunnat fastlägga att det finns skillnader mellan hur de arbetslösa tjänstemännen i undersökningen påverkas av arbetslösheten. Respondenterna fick ta ställning till en konkret fråga om stämningen i familjen påverkats av arbetslöshetssituationen. En del svarade att den försämrats, de flesta uppgav att det inte var någon skillnad jämfört med tidigare och andra tyckte att stämningen blivit bättre. Att det fanns skillnader var självfallet väntat, men vad är det som ligger bakom skillnaderna? Finns det bakomliggande faktorer som påverkar hur stämningen i familjen blir?

Den vanligast förekommande kommentaren till varför man upplever att arbetslösheten påverkat stämningen $\mathrm{i}$ familjen till det sämre hänger samman med ekonomiska svårigheter. Kontroverser mellan sammanboende/makar och mellan föräldrar och barn handlar i beskrivningarna ofta om pengar och om hur man skall prioritera för att pengarna skall räcka till. Detta kan ge upphov till spänningar i familjerna, som kan vara hinder för de sammanboende/makarna att prata om svåra saker med varandra. Konflikterna kring ekonomin förefaller vara den viktigaste enskilda faktor, som bidrar till en försämrad stämning i familjerna i varje fall mellan de vuxna. Även om åtskilliga kommentarer från respondenterna handlade om ekonomiska svårigheter som en orsak till konflikter med barnen, så finns det litet stöd för det $i$ analysen då vi kontrollerat för olika sociala bakgrundsvariabler. Visserligen fann vi en signifikant ökning av oddskvoten mellan dem som hade stora och de som hade små ekonomiska svårigheter och försämrad stämning mellan föräldrar och barn. Men differenserna var fyra gånger störreavseendestämningen mellan de vuxna och stora ekonomiska svårigheter. Man kan spekulera i om att det är de ekonomiska svårigheterna som leder till kontroverser om ekonomin mellan makarna som spills över på relationen mellan föräldrar och barn. Stora ekonomiska svårigheter kan utgöra ett existentiellt hot vars emotionella reaktion är djup oro (Starrin \& Jönsson, 1998; Jönsson \& Starrin, 2000).

Resultat i undersökningen visade på ett starkt samband mellan att hysa stor oro inför framtiden, dvs. vara utsatt för en stark psykisk påfrestning, och försämradstämningen i familjen. Detta gäller både för relationen mellan de vuxna och mellan föräldrar och barn. Oddskvoten för att hysa stor oro inför framtiden skiljer sig inte mellan de båda grupperna. Oro inför framtiden förefaller vara den faktor som starkast påverkar stämningen i familjen till det sämre. Men om det är oron som påverkar stämningen eller om stämningen påverkar oron kan vi inte vara helt säkra på. Det finns emellertid indikatorer som talar för att det kan vara oron inför framtiden som påverkar stämningen i familjen och inte tvärtom. Eisenberger och Lazarfeld (1938) och Komarovsky (1940) visade t.ex. i sina studier att arbetslösheten påverkar den arbetslöse känslomässigt och att detta påverkade hela familjen. Detta kan antas även gälla för de arbetslösa idag. Variabeln »oro inför framtiden« inbegriper olika aspekter av tillvaron: ekonomin, boende, livslust, självförtroende och hälsa. Att hysa stor oro för t.ex. att livslusten försämras, att förlora sitt självförtroende och få försäm- 
rad hälsa är känslomässigt pressande och ett uttryck för en slags känslomässig stress, som påverkar familjerelationerna. Vid kontroll fann vi att det inte förelåg någon genderskillnad i detta hänseende. Forskning har visat att socialt stöd är betydelsefullt för att den arbetslöse skall kunna bemästra sin situation (t.ex. Hartley,1987; Engbersen, m.fl., 1993; Pihl \& Starrin, 1998). Att ha någon att prata personliga saker med är ett viktigt socialt stöd. En stor andel bland tjänstemännen i undersökningen som anger att stämningen försämrats, saknar ofta någon att prata mer personliga saker med.

\section{Ett socialt stigma}

I sin bok Stigma beskriver Goffman (1973) en arbetslös mans reaktioner. Den skam över att vara arbetslös, som mannen uttrycker, menar Goffman, är ett uttryck för arbetslöshetens stigmatiserande drag. Många arbetslösa tjänstemän tycks också uppleva sin situation som stigmatiserande. En möjlig tolkning av resultatet är att stigmatisering $i$ form avskamgörandeerfarenheterhänger samman medhur den arbetslöse upplever omgivningensförhållningssätt gentemotarbetslösa och att stigmatiseringen manifesteras i känslan av att vara mindre värd och ha sämre självförtroende (se t.ex. Fineman, 1983; Jönsson \& Starrin, 1998b; Starrin \& Jönsson, 1998).

En del av respondenterna har beskrivit denna känsla som att man har "krympt", känner sig "värdelös», känner sig "misslyckad" och menar att relationerna inom familjen påverkas negativt. Den stigmatiserade individen avviker på ett icke önskvärt sätt från andra - de normala. För den som bär ett stigma ligger alltid skammen på lur, skriver Goffman, och pekar på att den stigmatiserade upplever utanförskap,kännersig mindervärdig och undviker att möta andra - drar sig undan (Goffman, 1973).

\section{Sammanfattningsvis}

Vi har i denna undersökning främst uppmärksammat två dimensioner kopplad till arbetslösheten: en ekonomisk dimension i form av huruvida man drabbats av ekonomiska svårigheter eller ej och en social dimension uttryck i olika erfarenheter och upplevelser som har samband med att vara arbetslös. Vi har kunnat konstatera att det föreligger samband mellan stora ekonomiska svårigheter, upplevelser av skam, grad av socialt stöd samt grad av oro inför framtiden och försämrad stämning i familjen. Ekonomiska svårigheter kan utgöra ett hot mot och utestänger familjen från delar av ett normalt socialt liv. Knapphet på pengar kan också framkalla känsla av skam. Man skäms för att vara fattig och för att inte kunna delta i det som man varit van vid. Flera skriver att deras barn inte förstår att det inte längre finns pengar till att göra saker som man gjort och att det blir bråk om pengar mellan makarna. Familjen kan inte längre leva upp till sociala förväntningar. Skamkänslan är kanske fastmer kopplad till hur man upplever sig bli bemött och behandlad av andra människor.

Sambandet mellan den ekonomiska och de sociala dimensionerna och försämrad stämning mellan familjemedlemmarna är påfallande. Även om det är svårt att med säkerhet i en tvärsnittsstudie uttala sig om sambandens kausalitet så är det inte desto mindre påfallande effekter som konstateras.

Leif R. Jönsson: Arbetslöshet och familjer 


\section{Litteratur}

Bakke,E, W (1933) The Unemployed Man. London: Nisbet.

Björnung-Andersson, M och Garsten, Chr. (1997) "Människor, attityder och beteenden. « I Berg, J, O, Förnyare, Frustrerade, och Fria agenter Rapport från ett forskningsprojekt om arbetslösheten och Den dolda världen. Stockholm: City University Press.

Broman, C, L, Hamilton, V, L, \& Hoffman, W, S (1990) "Unemployment and its effects on families: Evidence from a plant closing study." American Journal of Psychology, 18/5, 643-659.

Christofersen Nygaard, M (1994) "A follow-up study of longterm effects of unemployment on children: loss of self-esteem and self-destrucytive behavior among adolescents." Childhood, 4 , 212-220.

Christofersen Nygaard, M (1995) Sandsynlige sociale konsekvenser af arbejdsloshed. Kopenhavn: Social forsknings instituttet. Arbejdsnotat 1995:4.

Conger, R, D, Elder, G, H, Jr, Lorenz, F, O, Conger, K, J, Simons, R, L, Whitbeck, L, B, Huck, S, \& Melby, J, N (1990) "Linking economic hardship to martial quality and instability." Journal of Marriage and the Family, 52, 643-656.

Dhooge,Y \& Popay, J (1987) "Social services and unemployment: impact and respons. "IFineman, S(red) Unemployment. Personaland SocialConsequences. London: Tavistock publications.

Dial, P, W (1988) "Unemployment and family stress." Public welfare, 46/1, 30-34.

Engbersen, G, Schuyt, K, Timmer, J \& Van Waarden, $\mathrm{F}$ (1993) Cultures of unemployment: a comparative look at longterm unemployment and urban poverty. Bolulder: Westview Press.

Eisenberger, P \& Lazarsfeld, P, L(1938) »The psycological effects of unemployment." Psychological Bulletin, 35, 358-390.

Elder, G, H, Jr \& Caspi, A (1988) „Economic stress in lives: Development perspective.» Journal of Social Issues, 44/4, 25-45.

Fagin, L \& Little, M (1984) The Forsaken Families. The effect of Unemployment on Family life. Har- mondsworth: Penguin Books.

Fineman, S (1983) White Collar Unemployment. Impact and Stress. London: John Wiley \& Sons Ldt.

Flanagan, C,(1990) "Change in family work status." Child Development. 61/1 163-177.

Goffman, E (1973 Stigma: den avvikandes roll och identitet. Stockholm: Rabén \& Sjögren.

Hagquist, C \& Starrin, B (1994) »Barns hälsa och föräldrars arbetslöshet." Socialvetenskaplig tidskrift, 1/4, 287-301.

Hartley, J (1987) "Managerial unemployment: the wife's perspective and role.» I Fineman, S (red) Unemployment. PersonalandSocialConsequences. London: Tavistock publications

Hayes, J \& Nutman, P (1981) Understanding the unemployed. The psychological effects of unemployment. London: Tavistock Publications Ltd.

Jahoda, M, Lazarfeld P, L, Zeisel, H,(1933/1971) Marienthal The sociography of an unemployed community. Chicago: Aldine Atherton, Inc. Först publicerad 1933 som »Die Arbeitslosen von Marienthal».

Jahoda, M, Rush, H (1980) Work, employment and unemployment. An overview of ideas and reseach results in the social sience literature. SPRU Occasional Paper Series No. 12. Sience Policy Research Unit, University of Sussex.

Jahoda, M(1982) Employment and Unemployment. A social-psychological analysis. Cambridge: University Press.

Jahoda, M (1992) »Reflections on Marienthal and after." Journal of Occupational and Organizational Psychology, 65/1, 355-399.

Jönsson, LR, Söderfeldt, B \& Starrin, B (1996) "Om att leva utan arbete - arbetslösas upplevelser." I Bidrag genom arbete - en antologi. SOU 1996:151. Storstadskommittén, Socialdepartementet. Stockholm.

Jönsson, LR \& Starrin, B (1998a) "Arbetslösa tjänstemäns sociala och hälsomässiga situation." Meddelande från Socialhögskolan, Lunds universitet, 1998:3. 
Jönsson, LR (1998) "Arbetslösa privattjänstemän.» Meddelande från Socialhögskolan, Lunds universitet, 1998:4.

Jönsson, LR \& Starrin, B (1998b) „Ett annat liv. En studie av arbetslöshetens konsekvenser bland arbetslösa i Skåne." Meddelande från Socialhögskolan, Lunds universitet, 1998:5.

Jönsson, LR \& Starrin, B (2000) »Ekonomi-skam modellen och reaktioner på arbetslöshet." Socialvetenskaplig tidskrift. 7/3, 267-284.

Jönsson, LR (2001) »Arbetslöshet och stigmatisering."(Opublicerat manus).

Kessler R, C, Turner, J, B \& House, J, S (1987) Intervening processes in the relationship between unemloyment and health. Psychological Medicine, 17, 949-961.

Komarovsky, M(1940/1971) The Unemployed Man and His Family. New York: Arno Press Inc. Reprinted edition. Först publicerad 1940 i serien Poverty in U.S.A. The Historical Record. Institute of Social Research, Colombia University.

Lenkerd, B (1995) Psychosocial Consequences of Unemployment. A background study. Stockholm: City University Press.

Liem, R \& Liem, J, H (1988) »Psychological effects of unemployment on workers and their families." Journal of Social Issues, 44/4, 87-105.

Madge, N(1983) „Unemployment and its effects on children." Journal of Child Psychology and Psychiatry, 24/3, 311-319.
Näsman, E och Gerber von, C (1996) Mamma pappa utan jobb. Stockholm: Rädda Barnens förlag.

Pihl, A, Starrin, B (1998) „Ekonomiska påfrestningar, socialt stöd och ohälsa." Socialmedicinsk tidskrift 75/6 297-304.

Starrin, B (1997) "Arbetslösheten, familjen, barnen och skolan. "I Hagquist, C \& Starrin, B (red) När krisen slår till mot de unga! Stockholm: Gothia förlag.

Starrin, B\& Jönsson, LR (1998) „Ekonomisk påfrestning, skamgörande erfarenheter och ohälsa under arbetslöshet. "Arbetsmarknad \& Arbetsliv, 4/2, 91-108.

Starrin, B, Forsberg, E \& Rantakeisu,U (1999) »I arbetslöshetens spår - ekonomisk stress, skam och ohälsa.« IHärenstam, A, Lundberg, U, Lindbladh, E \& Starrin, B. (red.) I vanmaktens spår. Umeå:Boréa.

Vosler, N, R (1996) New approaches to family pratice-Confronting economic stress. London: Sage Publications.

Whelan, C (1992) »The Role of Income, Life-Style Deprivation and Financial Strain in Mediating the Impact of Unemployment on Psychological Distress: Evidence from the Republic of Ireland." Journal of Occupational and Organizational Psychology, 65/1, 331-345.

Zawadski, D och Lazarsfeld, P, F (1938) »The Psychological Consequences af Unemployment." Journal of Social Psychology, 6, 224-251.

\section{Summary \\ Unemployment and family relations}

The aim of the study was to investigate whether being unemployed affects relations in unemployed white-collar workers' families. The study is based on questionnaire data collected in May and June 1997, covering the whole of Sweden. The selection for the study consisted of members of the
Swedish Municipal Workers' Union (SKTF) unemployment insurance fund.

The results showed that 40 per cent of the unemployed white-collar workers in the study felt that their unemployment had had a negative effect on the atmosphere in the family. Almost half of the younger sub-

Leif R. Jönsson: Arbetslöshet och familjer 
jects said that relations had deteriorated, as opposed to 15 per cent in the older category. Those with high education, more so than those with low education, felt that unemployment had worsened the mood in their relationship with their spouse or partner. The full-time unemployed felt that the atmosphere had deteriorated more than the part-time employed. Some of the white-collar workers reported that unemployment had affected the family situation for the better. The family does more things together than they used to. For example, the husband plays a greater part in housework and is together with the children to a greater extent.

One third of both women and men stated that the relationship between them and their children had worsened. Subjects in early middle age reported more than others that the atmosphere had deteriorated. Loweducated reported more than high-educated that their relation to the children had become worse. Full-time unemployment, being involved in labour-market policy schemes, and the length of unemployment also seemed to have a negative effect on relationships between parents and children. Younger subjects reported a better relationship with children. This was expressed above all in women's comments. It felt good to be able to be with the children when they were small. Families with small children often said that relations were was better, whereas families with teenage children stated that they had become worse.

Serious economic difficulties seems to be a powerful contributory factor in the rise of controversies leading to a worse atmosphere in the family, especially between parents and teenage children. Social support and the degree of worry about the future show a strong correlation between the unemployment situation and worsened family relations. 